\title{
A human in vitro model system for investigating genome-wide host responses to SARS coronavirus infection Lisa FP Ng ${ }^{\dagger 1}$, Martin L Hibberd ${ }^{\dagger 1}{ }^{2}$, Eng-Eong Ooi ${ }^{3}$, Kin-Fai Tang ${ }^{3}$, Soek- Ying Neo ${ }^{1}$, Jenny Tan ${ }^{1}$, Karuturi R Krishna Murthy ${ }^{1}$, Vinsensius B Vega ${ }^{1}$, Jer- Ming Chia ${ }^{1}$, Edison T Liu ${ }^{1}$ and Ee-Chee Ren*1,2
}

Address: ${ }^{1}$ Genome Institute of Singapore, 60 Biopolis Street, Genome, \#02-01, Singapore 138672, 2Department of Microbiology, Faculty of Medicine, National University of Singapore, Block MD4, 5 Science Drive 2, Singapore 117597 and ${ }^{3}$ Enviromental Health Institute, National Environment Agency, 41 Science Park Road, \#03-24/28, The Gemini, Singapore Science Park II, Singapore 117610

Email: Lisa FP Ng - ngfp@gis.a-star.edu.sg; Martin L Hibberd - hibberdml@gis.a-star.edu.sg; Eng-Eong Ooi - gptoee@sgh.com.sg; KinFai Tang - gpttkf@sg.com.sg; Soek-Ying Neo - neosy3@gis.a-star.edu.sg; Jenny Tan - tanhh@gis.a-star.edu.sg; Karuturi R Krishna Murthy - karuturikm@gis.a-star.edu.sg; Vinsensius B Vega - vegav@gis.a-star.edu.sg; Jer-Ming Chia - jerm@gmx.net; Edison T Liu - liue@gis.astar.edu.sg; Ee-Chee Ren* - renec@gis.a-star.edu.sg

* Corresponding author †Equal contributors

Published: 09 September 2004

BMC Infectious Diseases 2004, 4:34 doi:10.1/86//47/-2334-4-34
Received: II June 2004

Accepted: 09 September 2004

This article is available from: http://www.biomedcentral.com/I47I-2334/4/34

(c) $2004 \mathrm{Ng}$ et al; licensee BioMed Central Ltd.

This is an open-access article distributed under the terms of the Creative Commons Attribution License (http://creativecommons.org/licenses/by/2.0), which permits unrestricted use, distribution, and reproduction in any medium, provided the original work is properly cited.

\begin{abstract}
Background: The molecular basis of severe acute respiratory syndrome (SARS) coronavirus (CoV) induced pathology is still largely unclear. Many SARS patients suffer respiratory distress brought on by interstitial infiltration and frequently show peripheral blood lymphopenia and occasional leucopenia. One possible cause of this could be interstitial inflammation, following a localized host response. In this study, we therefore examine the immune response of SARS-CoV in human peripheral blood mononuclear cells (PBMCs) over the first 24 hours.
\end{abstract}

Methods: PBMCs from normal healthy donors were inoculated in vitro with SARS-CoV and the viral replication kinetics was studied by real-time quantitative assays. SARS-CoV specific gene expression changes were examined by high-density oligonucleotide array analysis.

Results: We observed that SARS-CoV was capable of infecting and replicating in PBMCs and the kinetics of viral replication was variable among the donors. SARS-CoV antibody binding assays indicated that SARS specific antibodies inhibited SARS-CoV viral replication. Array data showed monocyte-macrophage cell activation, coagulation pathway upregulation and cytokine production together with lung trafficking chemokines such as IL8 and ILI7, possibly activated through the TLR9 signaling pathway; that mimicked clinical features of the disease.

Conclusions: The identification of human blood mononuclear cells as a direct target of SARS-CoV in the model system described here provides a new insight into disease pathology and a tool for investigating the host response and mechanisms of pathogenesis.

\section{Background}

The causative agent for SARS has been identified as a novel coronavirus [1-3] with genome sequence revealing no strong homology to existing known coronaviruses [4- 
6]. Coronaviruses belong to the family of enveloped viruses called Coronaviridae, and have the largest known single-stranded viral RNA genomes (27 to $32 \mathrm{~kb}$ ). Coronaviruses, have both "early" and "late" phases of gene expression. Regulatory proteins are synthesized as "early" non-structural proteins, while the structural proteins are synthesized as "late" proteins. "Late" structural proteins are usually required in greater amounts thus, there is a necessity to regulate the expression of the viral genes quantitatively. After the viral entry via endocytosis or through specific receptors, the 5 '-end of the viral genome is translated directly giving rise to twenty-three viral proteins, including the RNA dependent RNA polymerase (RdRp), and other functional products involved in transcription, replication, viral assembly and cell death. Coronaviruses can be classified into species and three major antigenic groups based on, serology, natural hosts, monoclonal antibody recognition and nucleotide sequencing [7]. Most coronaviruses have restricted host ranges as they infect only one host species or, at most, a few related species, they are an important group of animal pathogens. Group one (I) includes human coronavirus 229E (HCoV), porcine transmissible gastro-enteritis virus (TGEV) and feline enteric coronavirus (FECoV). Group two (II) includes bovine coronavirus ( $\mathrm{BCoV})$, murine hepatitis virus (MHV), and HCoV-OC43; and Group three (III) includes avian infectious bronchitis virus (IBV) [7]. Some coronaviruses like $\mathrm{HCoV}$ have restricted tissue tropism, including macrophages [8], although most strains that infect humans cause only mild respiratory infections.

However, SARS has rapidly caused a world-wide problem. The earliest known cases of SARS was reported in Guandong Province, China in November 2002, becoming more widespread by March 2003, when it was introduced to Canada, Singapore, Taiwan and Vietnam via Hong Kong. The largest number of infected patients has been in China with a worldwide incidence totalling more than 8,400 by July 2003 . Infection by the virus induces high morbidity and mortality, the latter being estimated at $15 \%$ by the World Health Organisation. SARS is characterized by high fever, non-productive cough or dyspnea and in many cases may progress to generalized, interstitial infiltrates in the lung, thus needing intubation and mechanical ventilation [2]. The characteristic compression of alveolar sacs seen in atypical pneumonia is largely due to fluid build up outside the alveoli. One possible cause of this could be interstitial inflammation, following a localised host response. To date, the details of the host response to SARS-CoV infection is still largely unknown and consequently the most appropriate treatment regime remains to be established. Typically a pro-inflammatory cytokine profile (up regulated TNFa, Il1, IL6 and IFNs) is seen in viral infections such as influenza [9], together with perhaps limited amounts of IL8 and other chemokines
[10] that may depend on which cell type is infected [11]. In experimental systems the immediate innate immune response has been shown to be directed by the monocytemacrophage-dendritic lineage to a range of different organisms $[12,13]$ and consists of a core set of pathways common to all, together with pathogen specific pathways. This data points to critical time points in the response, with the first 12 hours representing primary events while longer periods the consequence of this activity and a secondary (perhaps larger) cascade of responses.

We postulated that the pulmonary damage in SARS may not be a direct effect of the virus on the alveoli, but represents a secondary effect of cytokines or other factors proximal to but not from the lung tissue mediated by the host either as the primary or secondary response $[2,14]$. In this study, we have addressed this question by developing a human in vitro model system that will in the future allow detailed investigations of the host response to be made.

\section{Methods}

\section{Cell culture and virus infection}

PBMCs were obtained by Ficoll-Hypaque separation of whole blood. $2 \times 10^{5}$ PBMCs were seeded into each well of a 24-well culture plate, $0.5 \mathrm{ml}$ of complete RPMI- 1640 (Life Technologies-Invitrogen, USA) added to each and cultured overnight at $37^{\circ} \mathrm{C}\left(5 \% \mathrm{CO}_{2}\right)$. A seed stock of SARS-CoV (strain SIN 2774) passaged in Vero E6 cells was used for infection. Vero E6 culture supernatants were added to each well in $50 \mu \mathrm{l}$ volume at a concentration of 0.1 or $0.01 \mathrm{MOI}$ (based on plaque forming units) and a control plate (media only). Each culture was set up in duplicate. After 4 hours of incubation, one set of the duplicate wells of the control plate and a 4 hours incubation plate were harvested while the rest received $0.5 \mathrm{ml}$ media top-up and incubated for a further 2, 4, 6 and 8 days.

\section{Cell harvest and RNA isolation}

Harvesting was performed by gently flushing the wells with a Pasteur pipette to removed non-adherent cells, followed by a rinse of $1 \mathrm{ml}$ RPMI. The rinsed fraction was pooled with the first harvest aliquot and spun at 1500 $\mathrm{rpm}$. The cell pellet was washed twice with $2 \mathrm{ml}$ RPMI to remove virus in the supernatant. $1.5 \mathrm{ml}$ Trizol (Invitrogen, USA) was then added to the adherent cell fraction as well as the non-adherent cell fraction to lyse cells and stabilize the RNA. Extraction of total RNA was then performed following manufacturer's protocol and the resultant RNA dissolved in $40 \mu \mathrm{l}$ water.

\section{Real-time quantitative polymerase chain reaction (PCR)}

The amount of SARS-CoV in each cell fraction was measured by real-time quantitative PCR assay. $2 \mu \mathrm{l}$ of RNA was reverse transcribed and amplified in $20 \mu \mathrm{l}$ using $0.9 \mu \mathrm{M}$ 
each of forward (5'-GGTTGGGATTATCCAAAATGTGA-3') and reverse (5'-AGAACAAGAGAGGCCATTATCCTAAG$\left.3^{\prime}\right)$ primers, and $0.25 \mu \mathrm{M}$ of TaqMan ${ }^{\circledast} \mathrm{MGB}$ probe: $5^{\prime}$-(6FAM)AGAGCCATGCCTAACAT(NFQ)-3') in a one step PCR using master mix from Applied Biosystems (USA) according to manufacturers' recommendations. Reactions were performed using an ABI PRISM 7900 sequence detection system $\left(48^{\circ} \mathrm{C}\right.$ for $30 \mathrm{~min}$, followed by $95^{\circ} \mathrm{C}$ for 10 min and 40 cycles of $95^{\circ} \mathrm{C}$ for $15 \mathrm{sec}$ and $60^{\circ} \mathrm{C}$ for $1 \mathrm{~min}$ ) and quantitation achieved using standard curves generated from in vitro transcribed RNA.

\section{High density oligonucleotide array hybridization}

At each time point ( 4 hours, 8 hours, 12 hours, 24 hours), $5 \times 10^{7}$ cells of mock-infected and infected cells were harvested and lysed using Trizol (Invitrogen, USA). Total RNA was isolated according to the manufacturer's recommendation. Quality of the total RNA was judged from the ratio between $28 \mathrm{~S}$ and $18 \mathrm{~S}$ RNA after agarose gel electrophoresis. $20 \mu \mathrm{g}$ of total RNA was labeled with Cy-3 or Cy5 using the Superscript II reverse-transcription kit (Invitrogen, USA) and hybridization was carried out overnight (16 hours) at $42^{\circ} \mathrm{C}$ on high-density oligonucleotide arrays ( 19,200 gene features, Compugen) using universal human reference (Stratagene, USA) as a reference. Hybridized arrays were scanned at $5 \mu \mathrm{m}$ resolution on a GenePix 4000A scanner (Axon Instruments) with variable photo-multiplier tube voltage to obtain maximal signal intensities, and the resulting images were analyzed via GenePix Pro v4.0 (Axon Instruments) as described in the manual.

\section{Microarray data analysis}

Raw data were analyzed on GenePix analysis software version 4.0 (Axon Instruments) and uploaded to a relational database. The logarithmic expression ratio for a spot on each array was normalized by subtracting the median logarithmic ratio for the same array. Data were filtered to exclude spots with a size of less than $25 \mu \mathrm{m}$ and any poor quality or missing spots. Since the correlation of the overall data from reciprocal labeling was good, values obtained from reciprocal labeling experiments were averaged. In addition, the data were distilled to the set of gene features that were present at all 4 time points in both the viral infected samples and the negative controls. The results were represented as the logarithmic ratio of gene expression between the viral infected samples and their corresponding negative controls at the various time points. Application of these filters resulted in the inclusion of $\sim 12,900$ of the total $\sim 19,200$ gene features in subsequent analyses.

To discover patterns of gene expression, the values associated with each gene feature $f$ were translated so that their means were zero. Similar genes, whose translated gene- features exhibited same induction-repression pattern, were grouped together. Genes $g_{i} g_{j}$ were said to be similar if they satisfied the following condition:

$\sum_{t} U\left(g_{i t} * g_{j t}\right)=N$, where $U(x)=1$ if $x>0, U(x)=0$ otherwise,

where $g_{i t}$ and $g_{j t}$ denote the translated values of gene features $g_{i}, g_{j}$ at time $t$ respectively; and $N$ is the number of time points for which the expression of a gene was observed. Similar genes, based on the above criteria, are grouped together. Within each group, the genes were ordered in the descending order of their expression range (defined as the difference between the maximum and minimum ratios of gene expression). This algorithm is a special case of the Friendly Neighbor algorithm currently under development. The final plots were generated using the original expression ratios while preserving the clustering and ordering discovered by the above algorithm. To determine whether a gene observed to be responsive could appear merely by chance, 100,000 expression profiles were generated by randomly sampling the expression ratios from the entire dataset with replacement. The $P$ value of a gene is the fraction of the random profiles whose logarithmic expression range is as good as, or better than that of the selected gene.

\section{Results and Discussion Kinetics of SARS-CoV replication}

We obtained PBMCs from 6 healthy volunteers by FicollHypaque separation of whole blood. Of the 6 donor PBMCs tested, all were able to support SARS-CoV replication when infected with multiplicity of infection (MOI) of 0.1 . The first sampling, taken from cells infected for 4 hours, showed an average copy number of $32 \times 10^{3}$ (Fig. $1 \mathrm{~A})$ and represents the initial inoculum level. Over the course of the next 8 days, there was a steady rise in viral load, reaching as high as $480 \times 10^{3}$ copies per well in one donor, which could only be explained by active replication of the SARS-CoV intracellularly. This work is supported by recent in vivo evidence suggesting that SARS$\mathrm{CoV}$ may have infected and replicated within PBMCs of SARS patients [15] and cells from humans and animals [16]. An indication of the PBMCs lineage involvement was provided by repeating the experiment using the monocyte-macrophage cell line THP-1 [17], in which viral replication was similar to the primary cell culture over the first 4 days (Fig. 1B). In the primary cultures, the nonadherent cell fraction which comprises mainly lymphocytes and granulocytes showed dramatically less viral replication in our assay as did all cells infected at MOI of 0.01 (Fig. 1A).

The kinetics of viral replication was variable among the 6 donors (Fig. 1C). There was a lag phase of 2 days in the 
A

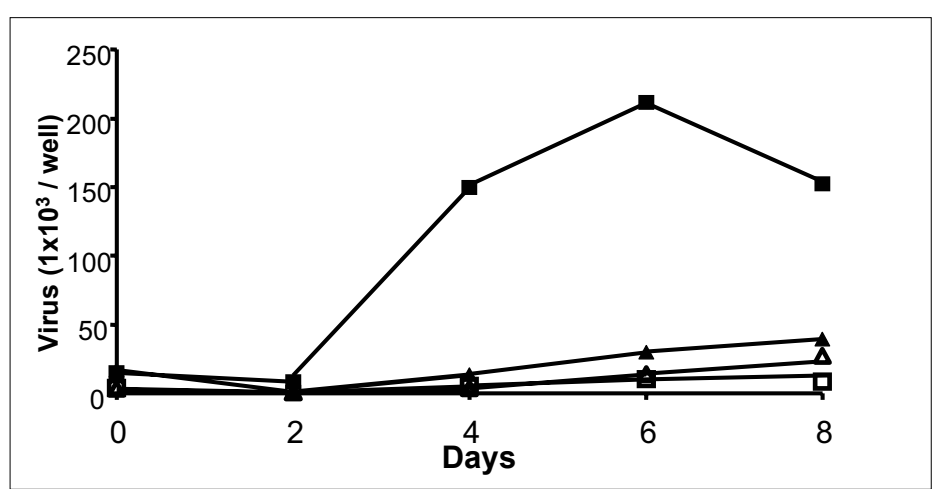

B

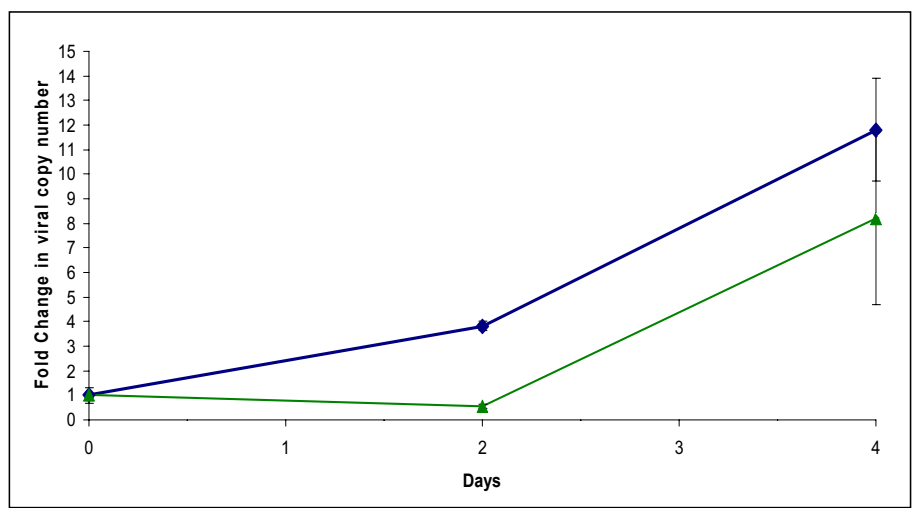

C
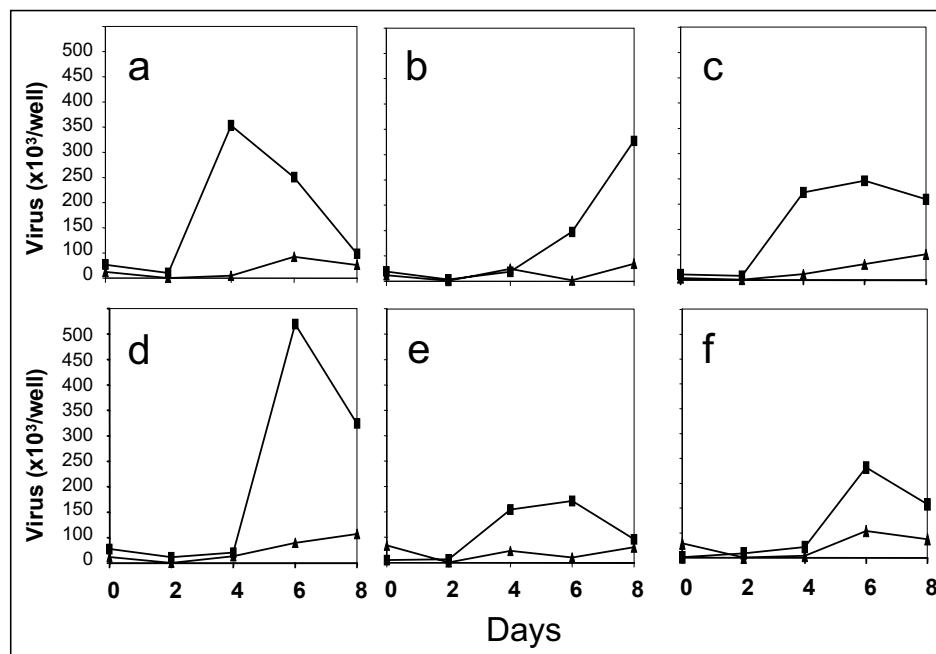

Figure I

Kinetics of SARS-CoV replication. A. Viral copy number per well during culture. Two MOI infecting doses were used, 0.1

$(\boldsymbol{\Delta}, \square)$ and $0.01(\square, \triangle)$ with $2 \times 10^{5}$ PBMCs/well. Harvested PBMCs were separated into two fractions, adherent cells (mostly macrophages), $(\square, \triangle)$ and suspended cells (mostly lymphocytes), $(\boldsymbol{\Lambda}, \square)$. Points represent the mean of six subjects, each done in duplicate. Increasing viral copy number is clearly seen in adherent cells using an $\mathrm{MOI}$ of $0 . \mathrm{I}$. There was little increase in viral load in non-adherent cells infected with SARS- CoV. B. Replication of SARS-CoV in the THP-I cell line. Using an MOI of 0.I, fold increase from day 0 in SARS-CoV infected THP-I cells $(\bullet)$ was similar to the PBMCs adherent fraction $(\mathbf{\Delta})$. Infections were done in duplicate and assayed in duplicate. Error bars represent SEM. C. Variation in the PBMC response to SARS-CoV infection. Using an $\mathrm{MOI}$ of $0 . \mathrm{I}$ adherent cells $(\boldsymbol{\square})$ but not suspended cells $(\boldsymbol{\Delta})$ showed differing lag phase length and viral replication in 6 subjects (a to f). Points show means of two replicates. 
case of donors a, $\mathrm{c}$ and $\mathrm{e}$; and 4 days for donors $\mathrm{b}, \mathrm{d}$ and $\mathrm{f}$ before any significant increase could be detected. The viral replication generally peaked at either day 4 or day 6 . The exception was donor $b$, in which the virus seemed to replicate at a much slower pace compared to the other 5 donor samples. Equally interesting was the different levels of virus attained. Donor d seems to stand out from the rest, reaching a peak of $480 \times 10^{3}$ copies per well which is 4 times more than that attained by donor e, with $120 \times$ $10^{3}$ copies per well. Such variation strongly suggests that there is an underlying host-pathogen interaction influencing the kinetics of SARS-CoV replication efficiency. These in vitro observations may reflect the wide range of patient outcomes after SARS-CoV infection [18].

Antibody blocking experiments were also performed in which SARS-CoV was pre-incubated with convalescent patient sera for 30 minutes before introduction to the PBMCs and after a 4 day incubation period, the adherent cell fraction was harvested and assayed for SARS-CoV viral titer. Results clearly showed that even at high dilution, convalescent sera inhibited SARS viral replication (data not shown), presumably by blocking viral entry. This supports other reports indicating that SARS-CoV is not endocytosed through antibody mediated mechanisms and confirms a protective role for antibodies elicited either by the infection or through immunization $[19,20]$.

\section{SARS-CoV specific gene expression changes}

To further elucidate the molecular processes of SARS-CoV infection, PBMCs from 3 healthy individuals were infected separately in vitro with SARS-CoV (0.1 MOI) and harvested at 4 hours, 8 hours, 12 hours and 24 hours time intervals post-infection. As controls, uninfected aliquots of the same PBMCs were also harvested at the corresponding time points. Total RNA extracted from the PBMCs of the 3 individuals were pooled, labeled and hybridized to human oligonucleotide arrays consisting of 19,200 gene features. Reciprocal dye swap replicate hybridizations were performed to minimize technical noise. Analysis of variance in expression levels for each gene across all the time points indicated the $\sim 1200$ genes which showed the largest variability (Fig. 2A and 2B).

In order to focus the analysis, we queried the entire data set for genes related to the immune response by keyword searches on their gene ontology descriptions with the aim of describing the specific host-pathogen interaction. In common with other studies of respiratory pathogens [913], our data points towards two critical time points in the response, with the first 12 hours representing a primary pro-inflammatory cytokine profile while longer periods represent the consequence of this activity and a secondary cascade of responses [9-13]. We observed that within the first 12 hours of SARS-CoV infection, evidence of this monocyte-macrophage activation was seen, indicated by enhanced expression of CD14, TLR9 plus NFK $\beta 1$ and GATA signaling (Fig. 2C and Table 1). In addition, the MRC2 endocytotic receptor was upregulated as was the complement pathway (C1q, C6). Taken together, these data suggest an early activation of the innate immunity pathway. This activation was accompanied by an unusual cytokine transcriptional profile (Fig. 2C and Table 1). While IL1 $\beta$ (up regulated for the first 12 hours) would be expected following macrophage activation [21], TNF $\alpha$, IFN $\gamma$ and IL6 were noted by their surprisingly low level of expression. This is in spite of the presence of elevated IL19 which is thought to enhance their up regulation [22]. In some clinical investigation, concentrations of TNF and IL 6 measured during active disease were found to be relatively low $[23,24]$, reflecting our findings. This paper did not report on IFN levels, however, we found them to be low (Supplementary figure [see Additional file 1]). This is of particular interest as IFNs have been shown to have significant anti-SARS-CoV effects [25]. Such effects suggest that alteration of the IFN response and perhaps other immune modulators might provide opportunity for novel treatment and management regimes for SARS patients to be developed.

A number of CC chemokines (CCL4, CCL20, CCL22, CCL25, CCL27) and their receptors (CCR4 and CCR7) were highly expressed in response to the infection (Fig. 2C and Table 1), indicating a rapid mobilization and increased trafficking, in particular of the monocyte-macrophage lineage very early on in the infection [26]. CXC chemokines (CXCL9, CXCL12) were also highly expressed suggesting significant increase in neutrophil homing as well. These are likely to be lung directed as IL8 and IL17 were also highly expressed [27-32]. Specific trafficking of these cells to the lung may account for the localized nature of the response [33].

Surprisingly, a number of blood coagulation genes were highly expressed early during our in vitro infection (Fig. 2C and Table 1), in particular TBXAS, which has been implicated in vasoconstriction, platelet aggregation, membrane lysis and increased permeability [34,35]; fibrin (FGB and FGG) and the coagulation pathway directly (SERPINs D1 and A3 together with Factors 10, 3 and 2). This gives a pro-coagulation profile, which mimics the clinical-pathological observations: at autopsy, many SARS patients have unusually disseminated small vessel thromboses in the lungs without evidence of disseminated intravascular coagulation [1,36]. Again, these expression profiles provide an experimental framework to explore an important aspect of SARS pathobiology and treatment. 
A
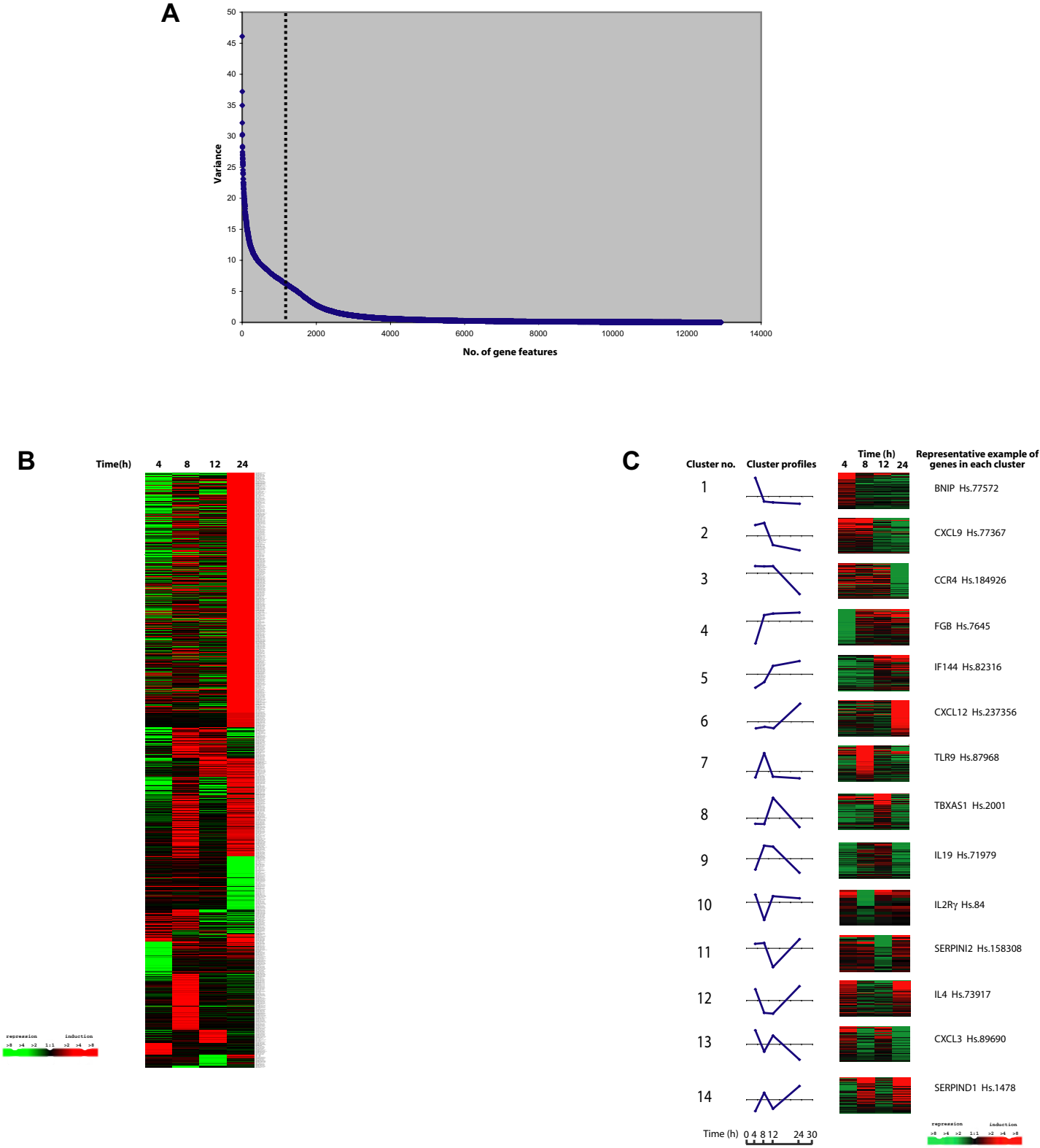

Figure 2

SARS specific gene expression changes. A. Plot showing the variance of expression ratio for each of the gene features across all the time points. Dotted line indicates the $\sim 200$ most variable gene features. B. Expression ratios of $\sim 200$ gene features as grouped by the algorithm as discussed in Methods. Rows represent individual genes, columns represent individual time points. Each cell in the matrix represents the mean expression level from 3 subjects for a gene feature at a particular time point (noninfected PBMCs responses have been subtracted from infected responses). The red and green color bars reflect high and low expression levels respectively, while black indicates equivalent expression level. The magnitude of the log-transformed ratio is reflected by the degree of color saturation. C. Levels of PBMCs mRNA expression of 1087 immune-related genes at 4 hours, 8 hours, 12 hours, and 24 hours in response to SARS-CoV infection were grouped and ordered using the algorithm described in Methods. Rows represent individual genes, columns represent individual time points. Each cell in the matrix represents the mean expression level from 3 subjects for a gene feature at a particular time point (non-infected PBMCs responses have been subtracted from infected responses). The red and green color bars reflect high and low expression levels respectively, while black indicates equivalent expression level. The magnitude of the log-transformed ratio is reflected by the degree of color saturation. The line graph indicates the average expression ratios for each group. The area above the axis indicates upregulation, while the area under the axis means downregulation. 
Table I: Representation of selected immune-related genes upregulated during the first $\mathbf{2}$ hours post-infection.

\begin{tabular}{|c|c|c|c|c|}
\hline Gene & Unique Gene ID. & Function & Expression range $\left(\log _{2}\right)$ & Cluster no. \\
\hline \multicolumn{5}{|c|}{ Immune Response Genes: } \\
\hline TGFBRI & Hs.220 & Cytokine proinflammatory & 10.66 & 4 \\
\hline CD36 & Hs.756I3 & Macrophage receptor & 8.61 & 3 \\
\hline TLR 9 & Hs.87968 & Macrophage activation & 7.11 & 7 \\
\hline MST & Hs.349IIO & Macrophage activation & 7.07 & 6 \\
\hline IL 19 & Hs.7I979 & Cytokine, proinflammatory & 6.86 & 9 \\
\hline CIQR & Hs. 97199 & Innate response & 6.31 & 7 \\
\hline C6 & Hs.I 282 & Innate response & 6.22 & 6 \\
\hline GATA3 & Hs. 169946 & Inflamation signaling & 6.14 & 9 \\
\hline MMD & Hs.79889 & Monocyte to macrophage & 6.13 & 7 \\
\hline CCL 25 & Hs.50404 & Chemokine, trafficking & 6.10 & 6 \\
\hline CXCL 12 & Hs.237356 & Chemokine, trafficking & 5.86 & 6 \\
\hline CCL 27 & Hs.225948 & Chemokine, trafficking & 5.34 & 6 \\
\hline C4BPB & Hs.99886 & Innate response & 5.12 & 6 \\
\hline CCR 4 & Hs. 184926 & Chemokine, trafficking & 5.11 & 3 \\
\hline $\mathrm{CCL} 4$ & Hs.75703 & Chemokine, trafficking & 4.62 & 3 \\
\hline IL I7C & Hs.II 0040 & Chemokine, trafficking & 4.25 & 14 \\
\hline IL I $\beta$ & Hs. 126256 & Cytokine, proinflammatory & 4.20 & 3 \\
\hline MRC 2 & Hs.7835 & Macrophage activation & 3.20 & 7 \\
\hline CXCL 9 & Hs.77367 & Chemokine, trafficking & 3.00 & 2 \\
\hline CCL 20 & Hs.75498 & Chemokine, trafficking & 2.88 & 3 \\
\hline CXCL 3 & Hs.89690 & Chemokine, trafficking & 2.79 & 13 \\
\hline CXCL 2 & Hs.75765 & Chemokine, trafficking & 2.78 & 3 \\
\hline CD 14 & Hs.75627 & Macrophage activation & 2.73 & 3 \\
\hline IL 8 & Hs.624 & Chemokine, trafficking & 2.70 & 3 \\
\hline$N F \kappa \beta I$ & Hs.83428 & Macrophage activation & 2.61 & 13 \\
\hline CCL 22 & Hs.97203 & Chemokine, trafficking & 2.60 & 3 \\
\hline CCR 7 & Hs. 1652 & Chemokine, trafficking & 2.55 & 9 \\
\hline \multicolumn{5}{|c|}{ Blood Coagulation Genes: } \\
\hline SERPINA3 ${ }^{\circ}$ & Hs.234726 & Inflammation activation & 9.39 & 3 \\
\hline SERPINI2 & Hs. 158308 & Proteinase inhibitor & 8.82 & 11 \\
\hline TBXAS I & Hs.200I & Blood coagulation & 7.70 & 8 \\
\hline FGB & Hs.7645 & Fibrin & 6.75 & 4 \\
\hline SERPINDI & Hs. 1478 & Blood coagulation & 6.69 & 14 \\
\hline SERPINII & Hs.78589 & Proteinase inhibitor & 6.68 & 6 \\
\hline SERPINA7 & Hs.76838 & Proteinase inhibitor & 6.60 & 7 \\
\hline GPIb $\alpha$ & Hs. 1472 & Platelet aggregation & 5.68 & 6 \\
\hline PROC & Hs.235I & Blood coagulation & 5.63 & 6 \\
\hline Factor 10 & Hs.47913 & Blood coagulation & 4.66 & 6 \\
\hline Factor 2 & Hs.76530 & Blood coagulation & 4.50 & 6 \\
\hline GP 9 & Hs.II 44 & Platelet aggregation & 4.02 & 6 \\
\hline Factor 3 & Hs.62192 & Blood coagulation & 3.60 & 2 \\
\hline FGG & Hs.7543I & Fibrin & 2.60 & 3 \\
\hline SEPPINEI & Hs.82085 & Anti-Fibrinolysis & 1.75 & 9 \\
\hline \multicolumn{5}{|c|}{ Signaling Genes: } \\
\hline UNC 13 & Hs. $15500 \mathrm{I}$ & Apoptosis induction & 11.19 & 4 \\
\hline CARD 4 & Hs. 19405 & Apoptosis, caspase activator & 10.68 & 14 \\
\hline TNFRSFI7 & Hs. 2556 & Apoptosis signaling & 10.19 & 14 \\
\hline ARL I & Hs.242894 & Cell-cell signaling & 8.66 & 2 \\
\hline LGALS 3 & Hs.79339 & Signaling, scavenger activity & 7.65 & 6 \\
\hline FAT & Hs. 166994 & Tumour suppressor & 7.15 & 2 \\
\hline TNFSF9 & Hs. I524 & Apoptosis signaling & 6.85 & 6 \\
\hline $\mathrm{BBC3}$ & Hs.87246 & Apoptosis signaling & 6.77 & 9 \\
\hline TNFRSFI $3 \beta$ & Hs.I5834I & Apoptosis signaling & 6.49 & 6 \\
\hline DDX24 & Hs. I55986 & Apoptosis signaling & 6.11 & 6 \\
\hline TNFRSFII $\beta$ & Hs.8I79I & Apoptosis signaling & 6.11 & 7 \\
\hline TNFRSFIO $\beta$ & Hs. 51233 & Apoptosis signaling & 6.09 & 6 \\
\hline BNIP2 & Hs. 155596 & Apoptosis signaling & 5.81 & 1 \\
\hline MGST 2 & Hs.8I874 & Cell-cell signaling & 5.50 & 6 \\
\hline
\end{tabular}


Table I: Representation of selected immune-related genes upregulated during the first I 2 hours post-infection. (Continued)

\begin{tabular}{|c|c|c|c|c|}
\hline CUL 4 & Hs. 183874 & Tumour suppressor & 5.35 & 6 \\
\hline BAF 53A & Hs. 274350 & Cell-cell signaling & 5.26 & 6 \\
\hline MAPK I & Hs.324473 & Apoptosis induction & 5.11 & 14 \\
\hline CUL 2 & Hs.82919 & Tumour suppressor & 5.09 & 6 \\
\hline P2RX I & Hs.41735 & Apoptosis, ion channel activity & 4.43 & 6 \\
\hline TYROBP & Hs.9963 & Intracellular receptor signaling & 2.51 & 13 \\
\hline $\mathrm{CNIH}$ & Hs.201673 & Intracellular signaling & 2.13 & 9 \\
\hline $\mathrm{ADR} \alpha \mid \mathrm{A}$ & Hs.52931 & Cell-cell signaling & 2.08 & 3 \\
\hline DAPK I & Hs. 153924 & Apoptosis induction & 2.01 & 9 \\
\hline \multicolumn{5}{|c|}{ Defense-related Genes: } \\
\hline TFF I & Hs.350470 & Defense response, maintenance & 7.65 & 9 \\
\hline TFF 3 & Hs.8296I & Extracellular defense response & 6.98 & 7 \\
\hline GAGE I & Hs. I2823I & Cellular defense response & 6.82 & 6 \\
\hline $\mathrm{DEF} \beta 3$ & Hs.283082 & Extracellular defense response & 6.01 & 5 \\
\hline RU 2 & Hs.6I345 & Extracellular defense response & 5.83 & 6 \\
\hline $\mathrm{DEF} \alpha 4$ & Hs. 2582 & Extracellular defense response & 5.81 & 6 \\
\hline \multicolumn{5}{|c|}{ Interferons-related Genes: } \\
\hline IFN $\alpha R \mid$ & Hs. 1513 & JAK-STAT cascade, recptor & $5.4 \mathrm{I}$ & 8 \\
\hline IRF 7 & Hs. 166120 & Transcription regulation & 5.05 & 6 \\
\hline IF I44 & $\mathrm{Hs} .82316$ & Invasive growth response & 2.69 & 5 \\
\hline IRF 6 & Hs.II80I & Transcription regulation & 2.06 & 14 \\
\hline IL 18 & Hs.83077 & Angiogenesis & 1.76 & 6 \\
\hline ISGF3 $\gamma$ & Hs. 1706 & Regulatory & 1.28 & 9 \\
\hline IRF 5 & Hs.334450 & Transcription regulation & 1.23 & 9 \\
\hline IFNaR2 & Hs.86958 & Receptor activity & 1.06 & 2 \\
\hline IFN $\gamma \mathrm{RI}$ & Hs. 180866 & Receptor activity & 0.80 & 5 \\
\hline $\mathrm{IFN} \gamma$ & Hs.856 & Growth regulation & 0.53 & 4 \\
\hline IRF 3 & Hs.75254 & Transcription regulation & 0.40 & 5 \\
\hline IRF 2 & Hs.83795 & Transcription regulation & 0.32 & 4 \\
\hline IRF I & Hs.80645 & Transcription regulation & 0.30 & 3 \\
\hline
\end{tabular}

Order is arranged from the highest to lowest value based on the expression range $\left(\log _{2}\right)$.

It is interesting to note that the TLR9 was highly expressed in comparison to other TLR receptors, implying some degree of TLR specificity for the virus (Fig. 3A). TLR9 is known to respond to CpG signaling motifs (GTCGTT) [37-39] and one possibility is that the virus is activating directly through this mechanism. In support of this, we found that the SARS-CoV viral sequence contains the highest number ( 7 copies) of such specific signaling motifs compared to other coronaviruses and significantly more than several other viruses involved in respiratory diseases (Fig. 3B). It is conceivable that TLR9 may be aiding host recognition of the virus via the $\mathrm{CpG}$ groups and contributing to the initiation of the innate host inflammatory response. An alternative explanation is that TLR9 is being stimulated by mechanisms unrelated to $\mathrm{CpG}$ recognition.

The emerging picture from this study implicates a central role for the immune response in the pathobiology of a SARS infection. While detailed in vivo studies of the host response are now required, the in vitro model described here will allow responses to specific modulators (such as therapeutics) to be investigated. In future developments of the model, it will be interesting to compare the host response to different SARS-CoV isolates with inactivated preparations of the virus. In other diseases, in vitro models have revealed a number of key processes relevant to the clinical diseases $[9,12,13]$ and it is likely that the responses identified here will prove to be equally important. Although some clinical parameters have now been used as prognostic markers [40-42], further study of the regulatory mechanisms for chemokine-cytokine production will likely improve their accuracy and perhaps allow development of new treatment protocols.

\section{Competing interests}

None declared.

\section{Authors' contributions}

LFPN, MLH, ETL and REC conceived the study, its design and coordination, results analysis and drafted the manuscript. EEO and KFT carried out the virus infections. SYN, KRKM, VNV and JMC were involved in the array and statistical analysis. JT carried out the real-time PCR assays. 
A

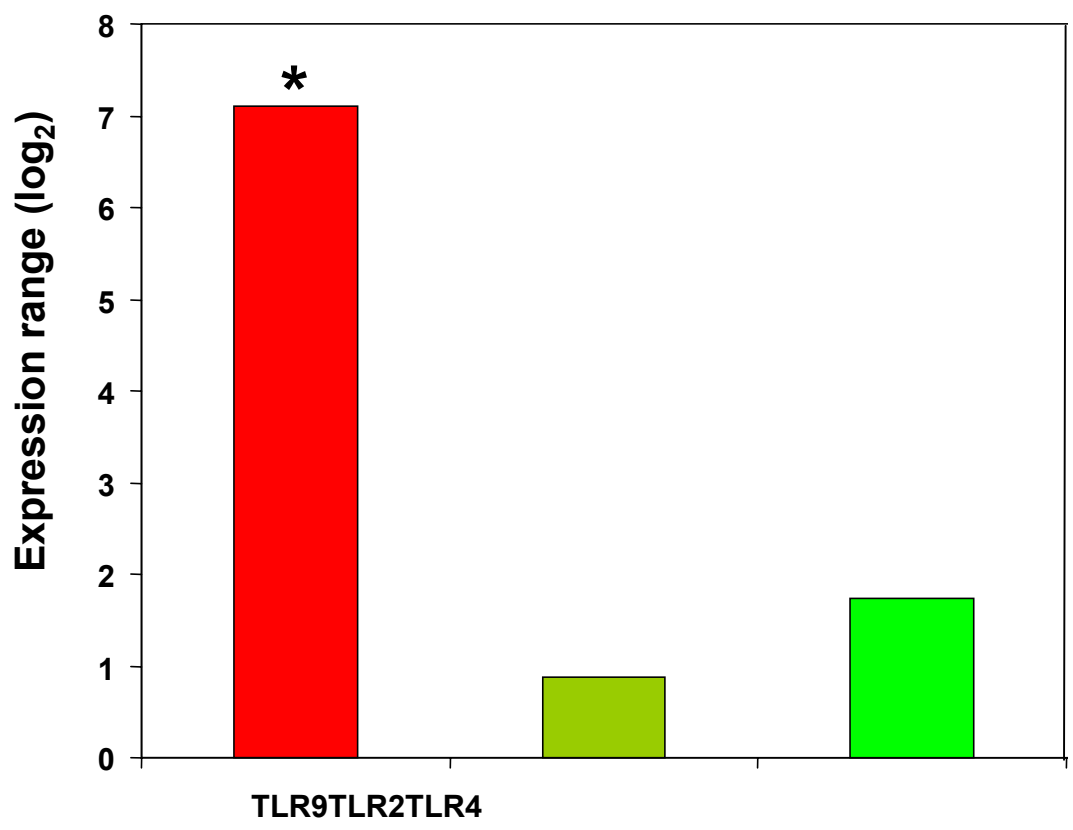

B

\begin{tabular}{ll}
\hline \multicolumn{1}{c}{ Virus } & (GTCGTT) copy number \\
\hline Coronaviruses: & 7 \\
SARS coronavirus GIS 2500 & 3 \\
Human coronavirus 229E & 6 \\
Murine hepatitis virus & 3 \\
Avian infectious bronchitis virus & 4 \\
Bovine coronavirus & \\
& \\
Viruses linked to respiratory diseases: & 0 \\
Human rhinovirus B & 0 \\
Human parainfluenza virus 1 & 0 \\
Human respiratory syncytial virus & 0 \\
Human metapnuemovirus & \\
\hline
\end{tabular}

Figure 3

Expression of TLR9 in response to SARS-CoV infection. A. Expression range $\left(\log _{2}\right)$ for TLR9, TLR2 and TLR4. The expression range for TLR9 was greater than expected (* represents a $P$-value for TLR9 of 0.016). B. Comparison of the CpG motif (GTCGTT) copy number in coronaviruses and other viruses linked to respiratory diseases. Accession numbers are as follows: SARS coronavirus SIN2500 - AY283794, Human coronavirus 229E - NC_002645, Murine hepatitis virus - NC_00I846, Avian infectious bronchitis virus - NC_00I45I, Bovine coronavirus - NC_003045, Human rhinovirus B - NC_00I490, Human parainfluenza virus I - NC_00346I, Human respiratory syncytial virus - NC_00I78I, Human metapneumovirus NC_004l48. 


\section{Additional material}

\section{Additional File 1}

List of all immune related genes after SARS-CoV infection Comprehensive list of 1087 immune related genes that were altered in PBMCs in response to SARS-CoV infection at 4 hours, 8 hours, 12 hours, and 24 hours. Genes were grouped and ordered using the algorithm described in Methods. Rows represent individual genes, columns represent individual time points. Each cell in the matrix represents the mean expression level from 3 subjects for a gene feature at a particular time point (non-infected $P B M C$ responses have been subtracted from infected responses). The red and green color bars reflect high and low expression levels respectively, while black indicates equivalent expression level. The magnitude of the log-transformed ratio is reflected by the degree of color saturation. The line graph indicates the average expression ratios for each group. The area above the axis indicates upregulation, while the area under the axis means downregulation.

Click here for file

[http://www.biomedcentral.com/content/supplementary/14712334-4-34-S1.pdf]

\section{Acknowledgment}

This study was supported by grants from the Agency for Science, Technology and Research (A*STAR), Singapore. Lisa F. P. Ng is also supported by a postdoctoral scholarship from the Singapore Millennium Foundation, Singapore Technologies. We thank Lora V. Agathe, Patricia Tay Pei-Wen, Khoo Chen-Ai and Li Pin (Genome Institute of Singapore); Renita Danabalan (National Environment Agency) for technical assistance and Dr Ling AiEe (Department of Pathology, Singapore General Hospital) for the SARS$\mathrm{CoV}$ isolate.

\section{References}

I. Peiris JSM, Lai ST, Poon LLM, Guan Y, Yam LY, Lim W, Nicholls J, Yee WK, Yan WW, Cheung MT, Cheng VC, Chan KH, Tsang DN, Yung $\mathrm{RW}, \mathrm{Ng} T \mathrm{TK}$, Yeun KY, SARS study group: Coronavirus as a possible caused of severe acute respiratory syndrome. Lancet 2003 , 36I:1319-1325.

2. Ksiazek TG, Erdman D, Goldsmith CS, Zaki SR, Peret T, Emery S, Tong S, Urbani C, Comer JA, Lim W, Rollin PE, Dowell SF, Ling AE, Humphrey CD, Shieh WJ, Guarner J, Paddock CD, Rota P, Fields B, DeRisi J, Yang JY, Cox N, Hughes JM, LeDuc JW, Bellini WJ, Anderson LJ, SARS Working Group: A novel coronavirus associated with severe acute respiratory syndrome. N Engl J Med 2003, 348: $1953-1966$.

3. Drosten C, Gunther S, Preiser W, van der Werf S, Brodt HR, Becker $\mathrm{S}$, Rabenau H, Panning M, Kolesnikova L, Fouchier RA, Berger A, Burguiere AM, Cinatl J, Eickmann M, Escriou N, Grywna K, Kramme S, Manuguerra JC, Muller S, Rickerts V, Sturmer M, Vieth S, Klenk HD, Osterhaus AD, Schmitz H, Doerr HW: Identification of a novel coronavirus in patients with severe acute respiratory syndrome. N Engl J Med 2003, 348: | 967-1976.

4. Marra MA, Jones SJM, Astell CR, Holt RA, Brooks-Wilson A, Butterfield YS, Khattra J, Asano JK, Barber SA, Chan SY, Cloutier A, Coughlin SM, Freeman D, Girn N, Griffith OL, Leach SR, Mayo M, McDonald H, Montgomery SB, Pandoh PK, Petrescu AS, Robertson AG, Schein JE, Siddiqui A, Smailus DE, Stott JM, Yang GS, Plummer F, Andonov A, Artsob H, Bastien N, Bernard K, Booth TF, Bowness D, Czub M, Drebot M, Fernando L, Flick R, Garbutt M, Gray M, Grolla A, Jones S, Feldmann H, Meyers A, Kabani A, Li Y, Normand S, Stroher U, Tipples GA, Tyler S, Vogrig R, Ward D, Watson B, Brunham RC, Krajden M, Petric M, Skowronski DM, Upton C, Roper RL: The genome sequence of the SARS-associated coronavirus. Science 2003, 300:1399-1404.

5. Rota PA, Oberste MS, Monroe SS, Nix WA, Campagnoli R, Icenogle JP, Penaranda S, Bankamp B, Maher K, Chen MH, Tong S, Tamin A,
Lowe L, Frace M, DeRisi JL, Chen Q, Wang D, Erdmann DD, Peret TC, Burns C, Ksiazek TG, Rollin PE, Sanchez A, Liffick S, Holloway B, Limor J, McCaustland K, Olsen-Rasmussen M, Fouchier R, Gunther S, Osterhaus AD, Drosten C, Pallansch MA, Anderson LJ, Bellini WJ: Characterization of a novel coronavirus associated with severe acute respiratory syndrome. Science 2003, 300:1394-1399.

6. Ruan YJ, Wei CL, Ling AE, Vinsensius V, Thoreau, Se-Thoe SY, Chia JM, Ng WP, Chiu KP, Lim L, Zhang T, Chan KP, Oon LE, Ng ML, Leo YS, Ng LFP, Ren EC, Stanton LW, Long PM, Liu ET: Comparative full-length genome sequence analysis of I4 SARS coronavirus isolates and common mutations associated with putative origins of infection. Lancet 2003, 361: 1779-1785.

7. Holmes KV: Coronaviridae and their replication. In «Fields Virology» Edited by: BN Fields, DM Knipe. Raven Press, New York; 1990:84I-856.

8. Wu GF, Perlman S: Macrophage infiltration, but not apoptosis, is correlated with immune-mediated demyelination following murine infection with a neutropic coronavirus. J Virol 1999, 73:877I-8780.

9. Cheung CY, Poon LL, Lau AS, Luk W, Lau YL, Shortridge KF, Gordon $S$, Guan Y, Peiris JSM: Induction of proinflammatory cytokines in human macrophages by influenza $A$ (H5NI) viruses: a mechanism for the unusual severity of human diseases? Lancet 2002, 360:1831-1837.

10. Julkunen I, Melen K, Nyqvist M, Pirhonen J, Sareneva T, Matikainen S: Inflammatory responses in influenza A virus infection. Vaccine 2000, 19:S32-S37.

II. Arndt U, Wennemuth G, Barth P, Nain M, Al-Abed Y, Meinhardt A, Gemsa D, Bacher M: Release of macrophage migration inhibitory factor and CXCL8/interleukin-8 from lung epithelial cells rendered necrotic by influenza A virus infection. J Virol 2002, 76:9298-9306.

12. Nau GJ, Richmond JFL, Schlesinger A, Jennings E., Lander ES, Young $R$ : Human macrophage activation programs induced by bacterial pathogens. Proc Natl Acad Sci USA 2002, 99: 1503-I508.

13. Huang Q, Liu DY, Majewski P, Schulte LC, Korn JM, Young RA, Lander $E S$, Hacohen $\mathrm{N}$ : The plasticity of dendritic cell responses to pathogens and their components. Science 200I, 294:870-875.

14. Nicholls JM, Poon LL, Lee KC, Ng WF, Lai ST, Leung CY, Chu CM, Hui PK, Mak KL, Lim W, Yan KW, Chan KH, Tsang NC, Guan Y, Yue KY, Peiris JS: Lung pathogen of fatal severe acute respiratory syndrom. Lancet 2003, 36 I: $1773-1778$.

15. Li L, Wo J, Shao J, Zhu H, Wu N, Li M, Yao H, Hu M, Dennin R: SARS-coronavirus replicates in mononuclear cells of peripheral blood (PBMCs) from SARS patients. J Clin Virol 2003, 28:239-244.

16. Gillim-Ross L, Taylor J, Scholl DR, Ridenour J, Masters PS, Wenworth $D E$ : Discovery of novel human and animal cells infected by the severe acute respiratory syndrome coronavirus by replication-specific multiplex reverse transcription-PCR. J Clin Microbiol 2004, 42:31 96-3206.

17. Raza MW, Blackwell CC, Elton RA, Weir DM: Bacterial activity of a monocytic cell line (THP-I) against common respiratory tract bacterial pathogens is depressed after infection with respiratory syncytial virus. J Med Microbiol 2000, 49:227-233.

18. Singh K, Ooi EE, Kumarsil B, Saw S, Sethi S: Severe acute respiratory syndrome without respiratory symptoms or abnormal chest radiograph findings. Clin Infect Dis 2004, 38:585-586.

19. Traggiai E, Becker S, Sbbarao K, Kolesnikova L, Uematsu Y, Gismondo MR, Murphy BR, Rappuoli R, Lanzavecchia A: An efficient method to make human monoclonal antibodies from memory $B$ cells: potent neutralization of SARS coronavirus. Nat Med 2004, I0:87|-875.

20. Shi Y, Wan Z, Li L, Li P, Li C, Ma Q, Cao C: Antibody responses against SARS-coronavirus and its nucleocapsid in SARS patients. J Clin Virol 2004, 3 I:66-68.

21. Gordon S: Alternative activation of macrophages. Nat Rev Immunol 2003, 3:23-35.

22. Liao YC, Liang WG, Chen FW, Hsu JH, Yang JJ, Chang MS: IL-I 9 induces production of IL-6 and TNF-alpha and results in cell apoptosis through TNF-alpha. J Immunol 2002, 169:4288-4297.

23. Beijing Group of National Research projects for SARS: Dynamic changes in blood cytokine levels as clinical indicators in severe acute respiratory syndrome. Chin Med J 2003, I 16:1283-1287. 
24. To K, Tong JH, Chan PK, Au FW, Chim SS, Chan AK, Cheung JL, Liu EY, Tse V, Lo AW, Lo D, Ng H: Tissue and cellular tropism of the coronavirus associated with severe acute respiratory syndrome: an in-situ hybridization study of fatal cases. J Pathol 2004, 202:157-163.

25. Cinatl J, Morgenstern B, Bauer G, Chandra P, Rabenau H, Doerr HW: Treatment of SARS with human interferons. Lancet 2003, 362:293-294.

26. Robertson MJ: Role of chemokines in the biology of natural killer cells. J Leukoc Biol 2002, 71:173-183.

27. Miyamoto M, Prause O, Sjostrand M, Laan M, Lotvall J, Linden A: Endogenous IL- I7 as a mediator of neutrophil recruitment caused by endotoxin exposure in mouse airways. J Immunol 2003, I 70:4665-4672.

28. Drost EW, MacNee W: Potential role of IL-8, platelet-activating factor and TNF-alpha in the sequestration of neutrophils in the lung: effects on neutrophil deformability, adhesion receptor expression, and chemotaxis. Eur J Immunol 2002, 32:393-403.

29. Aggarwal A, Baker CS, Evans TW, Haslam PL: G-CSF and IL-8 but not GM-CSF correlate with severity of pulmonary neutrophilia in acute respiratory distress syndrome. Eur Respir J 2000, I5:895-90|.

30. Buhling F, Ittenson A, Kaiser D, Tholert G, Hoffmann B, Reinhold D, Ansorge S, Welte T: MRP8/MROI4, CDIIb and HLA-DR expression of alveolar macrophages in pneumonia. Immunol Lett 2000, 7 I: $185-190$.

31. Sar B, Oishi K, Matsushima K, Nagatake T: Induction of interleukin 8 (IL-8) production by pseudomonas nitrite reductase in human alveolar macrophages and epithelial cells. Microbiol Immunol 1999, 43:409-4I7.

32. Pace E, Gjomarkaj M, Melis M, Profita M, Spatafora M, Vignola AM, Bonsignore $\mathrm{G}$, Mody $\mathrm{CH}$ : Interleukin-8 induces lymphocyte chemotaxis into the pleural space. Role of pleural macrophages. Am J Respir Crit Care Med 1999, 159:1592-1599.

33. Ng PC, Lam CW, Li AM, Wong CK, Cheng FW, Leung TF, Hon EK, Chan IH, Li CK, Fung KS, Fok TS: Inflammatory cytokine profile in children with severe.

34. Ball HA, Cook JA, Wise WC, Halushka PV: Role of thromboxane, prostaglandins and leukotrienes in endotoxic and septic shock. Intensive Care Med 1986, I 2: I 16-I26.

35. Zaitsu M, Hamasaki Y, Nishimura S, Matsuo M, Fujita I, Thromboxane IE: Thromoxane synthesis is increased by upregulation of cytosolic phospholipase A2 and cyclooxygenase-2 in peripheral polymorphonuclear leukocytes during bacterial infection in childhood. Am J Hematol 2003, 72: I I5- 120.

36. Franks TJ, Chong PY, Chui P, Galvin JR, Lourens RM, Reid AH, Selbs E, McEvoy CP, Hayden CDL, Fukuoka J, Taubenberger JK, Travis W: Lung pathology of severe acute respiratory syndrome (SARS): a study of 8 autopsy cases from Singapore. Hum Pathol 2003, 34:729.

37. Akira S, Hemmi H: Recognition of pathogen-associated molecular patterns by TLR family. Immunol Lett 2003, 85:85-95.

38. Hornung $\mathrm{V}$, Rothenfusser S, Britsch S, Krug A, Jahrsdorfer B, Giese T, Endres S, Hartmann G: Quantitative expression of toll-like receptor I- 10 mRNA in cellular subsets of human peripheral blood mononuclear cells and sensitivity to CpG oligodeoxynucleotides. J Immunol 2002, 168:453I-4537.

39. Hemmi H, Takeuchi O, Kawai T, Kaisho T, Sato S, Sanjo H, Matsumoto M, Hoshino K, Wagner H, Takeda K, Akira S: A Toll-like receptor recognizes bacterial DNA. Nature 2000, 408:740-745.

40. Zou Z, Yang Y, Chen J, Xin S, Zhang W, Zhou X, Mao Y, Hu L, Liu D, Chang B, Chang W, Liu Y, Ma X, Wang Y, Liu X: Prognostic factors for severe acute respiratory syndrome: a clinical analysis of 165 cases. Clin Infect Dis 2004, 38:483-489.

41. Paul NS, Chung T, Konen E, Roberts HC, Rao TN, Gold WL, Mehta S, Tomlinson GA, Boylan CE, Grossman H, Hong HH, Weisbrod GL: Pattern of disease in patients with severe acute respiratory syndrome. AJR Am J Roentgenol 2004, I 82:493-498.

42. Su CP, Chiang WC, Ma MH, Chen SY, Hsu CY, Ko PC, Tsai KC, Fan CM, Shih FY, Chen SC, Chen YC, Chang SC, Chen WJ: Validation of a novel severe acute respiratory syndrome scoring system. Ann Emerg Med 2004, 43:34-42.

\section{Pre-publication history}

The pre-publication history for this paper can be accessed here:

http://www.biomedcentral.com/1471-2334/4/34/prepub
Publish with Biomed Central and every scientist can read your work free of charge

"BioMed Central will be the most significant development for disseminating the results of biomedical research in our lifetime. "

Sir Paul Nurse, Cancer Research UK

Your research papers will be:

- available free of charge to the entire biomedical community

- peer reviewed and published immediately upon acceptance

- cited in PubMed and archived on PubMed Central

- yours - you keep the copyright

Submit your manuscript here:

http://www.biomedcentral.com/info/publishing_adv.asp
BioMedcentral 